JAMP: Jurnal Adminitrasi dan Manajemen Pendidikan

Volume 2 Nomor 3 September 2019, Hal : 107-113

Tersedia Online di http://journal2.um.ac.id/index.php/jamp/

ISSN 2615-8574 (online)

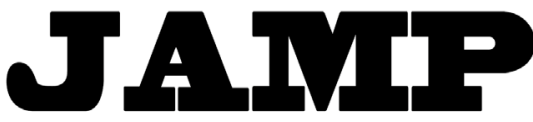

JURNAL ADMINISTRASI DAN MANAJEMEN PENDIDIKAN

\title{
MUATAN LIFE SKILLS DALAM KURIKULUM 2013 DAN MANAJEMEN PEMBELAJARANNYA
}

\author{
Desy Dwi Akhadiyah \\ Nurul Ulfatin \\ Desi Eri Kusumaningrum
}

Universitas Negeri Malang, Jalan Semarang 5 Malang 65145

Email: deasy.dwie@gmail.com

\begin{abstract}
: the purpose of this research was to describe the charge life skills curriculum in 2013 and the lesson that in the primary management of muhammadiyah malang 9 . This study used a qualitative approach. The data collected by the method of interview, observation, and documentation. The results of this research are (1) the structure of the curriculum applied in 2013 SD Muhammadiyah Malang 9 which includes basic competencies, core competencies, the subjects, and the burden of learning (2) types of life skills curriculum is contained in what the 2013 in SD Muhammadiyah Malang 9 which includes social skills and personal skills (3) setting a variety of life skills learning activities in the in SD Muhammadiyah Malang 9 covers personal skills and social skills (4) learning resources used for optimization of the curriculum learning-laden social skills and personal skills in SD Muhammadiyah Malang 9.
\end{abstract}

Keywords: life skills, curriculum, learning management

\begin{abstract}
Abstrak: Tujuan penelitian ini untuk mendeskripsikan muatan life skills dalam kurikulum 2013 dan manajemen pembelajarannya di sd muhammadiyah 9 malang. Penelitian ini menggunakan pendekatan kualitatif. Data yang dikumpulkan dengan metode wawancara, observasi, dan dokumentasi. Hasil dari penelitian ini adalah (1) struktur kurikulum 2013 yang diterapkan di SD Muhammadiyah 9 Malang yang mencakup kompetensi inti, kompetensi dasar, mata pelajaran, dan beban belajar (2) jenis-jenis life skills apa yang termuat dalam kurikulum 2013 di SD Muhammadiyah 9 Malang yang mencakup kecakapan personal dan kecakapan sosial (3) pengaturan macam-macam life skills tersebut dalam kegiatan pembelajaran di SD Muhammadiyah 9 Malang mencakup kecakapan personal dan kecakapan sosial (4) sumber-sumber belajar yang digunakan untuk optimalisasi pembelajaran kurikulum yang bermuatan kecakapan personal dan kecakapan sosial di SD Muhammadiyah 9 Malang.
\end{abstract}

Kata Kunci: life skills, kurikulum, manajemen pembelajaran

Kurikulum perlu direncanakan sedemikian rupa agar mencapai tujuan pendidikan. Tujuan pendidikan institusional adalah tujuan yang dikembangkan di suatu lembaga pendidikan. Di dalam tujuan institusional terdapat tujuan kurikuler. Tujuan kurikuler merupakan penjabaran tujuan instutisional yang harus dicapai oleh setiap bidang studi pada lembaga pendidikan tertentu. Tujuan pendidikan nasional yang tercantum dalam Undang-Undang Nomor 20 tahun 2003 tentang Sistem Pendidikan Nasional pasal 3, yaitu mengembangkan kemampuan peserta didik menjadi manusia yang beriman dan bertakwa kepada Tuhan Yang Maha Esa, berakhlak mulia, sehat, berilmu, kreatif ,terampil, mandiri, dan menjadi warga negara yang demokratis serta bertanggung jawab.

Salah satu kunci agar peserta didik dapat hidup secara mandiri yaitu life skills (kecakapan hidup). Life skills sendiri menurut Broling (dalam Wahab 2012) adalah interaksi berbagai pengetahuan dan kecakapan yang sangat penting dimiliki oleh seseorang, sehingga mereka dapat hidup mandiri. Life 
skills menurut Wahab (2012) adalah kesanggupan dan keberanian dalam menghadapi persoalan hidup kemudian secara kreatif dan proaktif menemukan solusi untuk mengatasi problema. Dari beberapa pendapat mengenai pengertian life skills, dapat disimpulkan bahwa life skills adalah suatu kecakapan yang dimiliki manusia yang dibutuhkan sebagai dasar untuk hidup mandiri dalam berkehidupan di tengah masyarakat.

Pendidikan life skills yaitu pendidikan yang memberi bekal dasar dan pelatihan yang diberikan kepada peserta didik tentang nilai-nilai kehidupan yang dibutuhkan dan berguna untuk perkembangan kehidupan peserta didik. Dengan demikian pendidikan life skills harus dapat memberikan proses pengajaran yang merefleksikan kehidupan nyata agar peserta didik memperoleh kecakapan hidup, sehingga peserta didik dapat siap untuk hidup di tengah-tengah masyarakat. (Yuliwulanda, 2017)

Life skills sangat dibutuhkan oleh manusia agar bisa hidup dan beradaptasi di masyarakat. Apalagi tuntutan dari perkembangan zaman yang semakin pesat, membutuhkan orang-orang yang tidak hanya berpendidikan saja, tetapi terampil dalam hidup mandiri. Dibutuhkan orang yang memiliki kecerdasan intelektual, emosional, dam spiritual serta kreatifitas dan keterampilan yang bisa bermanfaat bagi kehidupannya. Fungsi dari lembaga pendidikan penting sebagai wadah bagi peserta didik untuk dapat mengembangkan potensi yang ada dalam peserta didik.

\section{METODE}

Pada penelitian ini peneliti menggunakan pendekatan kualitatif. Alasan peneliti dalam menggunakan pendekatan kualitatif adalah peneliti ingin mengkaji dan menuangkan berbagai informasi maupun pengetahuan terkait objek yang diteliti mengenai muatan life skills dalam kurikulum 2013 dan manajemen pembelajarannya, dimana data dipaparkan secara naratif. Jenis penelitian ini termasuk fenomenologi karena berusaha mengungkapkan fenomena yang ada yaitu mengenai kurikulum dengan muatan life skills meliputi kecakapan personal dan kecakapan sosial. Berdasarkan jumlah kasus yang diteliti, penelitian ini termasuk kedalam jenis studi kasus tunggal karena penelitian ini hanya menggunakan satu lokasi untuk objek peneitian. Apabila dilihat dari aspek pelaporannya, penelitian ini merupakan studi kasus deskripktif yang digunakan untuk menjawab masalah penelitian.

Sumber data dalam penelitian ini berdasarkan dari hasil wawancara, observasi, dokumentasi. Narasumber yang ditujukan dalam penelitian ini yakni Kepala Sekolah, Kepala Urusan bagian Kurikulum, Kepala Urusan bagian Kesiswaan, Guru dan Peserta Didik. Peneliti juga menggunakan teknik observasi melalui pengamatan secara langsung. Pengamatan ini bertujuan untuk mengamati bagaimana kondisi sekolah dan proses pembelajaran di sekolah. Sumber data dokumentasi, digunakan sebagai data pendukung dari objek yang diteliti dalam penelitian ini yaitu kalender akademik, jadwal pelajaran, silabus, dan foto-foto pendukung proses pembelajaran. Lokasi penelitian yang digunakan sebagai objek penelitian merupakan SD Muhammadiyah 9 Malang yang berlokasi di Jl. R. Tumenggung Suryo No.5, Rampal Celaket, Blimbing, Kota Malang.

\section{HASIL}

\section{Struktur Kurikulum 2013 di SD Muhammadiyah 9 Malang}

Struktur Kurikulum di SD Muhammadiyah 9 Malang pada umumnya sama dengan sekolah negeri lain yakni menggunakan acuan kurikulum 2013, sebagai acuan kurikulum terbaru yang berlaku di Indonesia. SD Muhammadiyah 9 Malang menggunakan kurikulum yang utama yaitu kurikulum 2013 sebagai acuan kurikulum yang berlaku pada sistem pendidikan di Indonesia dengan pembelajaran di tingkat sekolah dasar menggunakan pendekatan tematik. Untuk ismuba sendiri merupakan ciri khas dari lembaga pendidikan muhammadiyah. Ismuba merupakan singkatan dari islam, muhammadiyah dan bahasa arab.

Struktur kurikulum pada umumnya mencakup kompetensi inti, kompetensi dasar, mata pelajaran, dan beban belajar. Struktur kurikulum pada jenjang sekolah diatur oleh pemerintah dalam peraturan 
menteri pendidikan dan kebudayaan nomor 67 tahun 2013 tentang kerangka dasar dan struktur kurikulum sekolah dasar/madrasah ibtidaiyah. Pada dasarnya setiap jenjang sekolah dasar di Indonesia penerapan kurikulum mengacu pada peraturan pemerintah di Indonesia. Sekolah perlu merapkan kurikulum 2013 dengan penyusunannya melibatkan beberapa pihak di sekolah yaitu kepala sekolah, guru, komite sekolah dan tokoh-tokoh yang berkaitan dalam penyusunan kurikulum. Penyusunan kurikulum juga secara teknis menyusun jadwal, kalender, dan materi.

Struktur kurikulum SD Muhammadiyah 9 Malang meliputi substansi pembelajaran yang ditempuh selama enam tahun. Struktur kurikulum ini disusun berdasarkan standar kompetensi lulusan dan standar kompetensi mata pelajaran. Mata pelajaran di SD Muhammadiyah 9 Malang terdiri dari Pendidikan Agama, Pendidikan Kewarganegaraan, Bahasa Indonesia, Matematika, Ilmu Pengetahuan Alam, Seni Budaya dan Keterampilan, Pendidikan Jasmani dan Olahraga, Keterampilan Komputer. Beban belajar di SD Muhammadiyah 9 Malang, untuk kelas satu 30 jam per minggu; kelas dua 32 jam per minggu; kelas tiga 34 jam per minggu; kelas empat, lima dan enam, 41 jam per minggu.

\section{Jenis-Jenis Life skills yang Termuat dalam Kurikulum 2013 di SD Muhammadiyah 9 Malang}

Berdasarkan hasil penelitian yang dilakukan pada jenjang sekolah dasar pada umumnya mengedepankan aspek General Life skills dalam pengembangan kecakapan hidup. General Life skills sendiri terdiri atas kecakapan personal dan kecakapan sosial. Kecakapan personal mencakup kecakapan memahami sendiri dan kecakapan berpikir. Kecakapan memahami sendiri di SD Muhammadiyah 9 Malang dapat diperoleh melalui kegiatan intrakurikuler dan kegiatan ekstrakurikuler. Kegiatan intrakurikuler dapat dilihat dari kecenderungan minat peserta didik dalam mengikuti suatu mata pelajaran di sekolah. Hal ini dapat membantu peserta didik dalam memahami apa yang menjadi kebiasaan dan kegemarannya. Kegiatan ekstrakurikuler juga mampu mendorong peserta didik dalam memahami apa yang menjadi kegemarannya. Kegiatan intrakurikuler maupun ekstrakurikuler dapat membantu peserta didik untuk memahami jati diri, kebiasaan, dan kegemarannya hal itu diperlukan agar peserta didik dapat mengaktualisasikan diri dan menemukan kepribadiannya.

Kecakapan berpikir dalam hal ini juga mendukung dalam pengembangan kecakapan personal. Kecakapan berpikir dapat di SD Muhammadiyah 9 Malang diperoleh melalui kegiatan intrakurikuler dimana peserta didik secara aktif mengikuti pembelajaran di kelas, mampu mengerjakan tugas atau soal yang diberikan oleh guru, mampu mengambil keputusan secara cerdas. Proses tersebut dapat mendukung pengembangan aspek kecakapan berpikir dimana peserta didik mampu mengatasi tugas maupun tanggung jawab sebagai peserta didik dan mampu mengembangkan pola pikir peserta didik menjadi kritis.

Kecakapan sosial terdiri atas kecakapan berkomunikasi dan kecakapan bekerjasama. Kecakapan berkomunikasi di SD Muhammadiyah 9 Malang dapat diperoleh melalui interaksi peserta didik di sekolah baik antara peserta didik dengan peserta didik, peserta didik dengan guru, maupun peserta didik dengan masyarakat di lingkungan sekitar. Kecakapan berkomunikasi tersebut dapat dilatih melalui kegiatan pembelajaran di sekolah dimana di kelas peserta didik dituntut aktif berkomunikasi.

Kecakapan bekerjasama di SD Muhammadiyah 9 Malang dapat diperoleh peserta didik melalui kegiatan pengerjaan tugas secara berkelompok. Pengerjaan tugas secara berkelompok juga mampu membantu mengembangkan sikap saling pengertian antar sesama karena pada hakikatnya manusia adalah mahluk sosial yang tidak lepas dari bantuan orang lain dalam menyelesaikan tantangan hidup sehari-hari.

\section{Penerapan Macam-Macam Life skills dalam Kegiatan Pembelajaran}

Penerapan macam-macam life skills tersebut dapat diperoleh baik dalam kegiatan intrakurikuler, ekstrakurikuler, maupun kokurikuler. Penerapan kegiatan intrakurikuler tidak lepas dari muatan pembelajaran yang sudah direncanakan. Untuk mempermudah proses pembelajaran diperlukan 
penyusunan Rancangan Pelaksanaan Pembelajaran (RPP). Rancangan pelaksanaan pembelajaran tersebut disusun sedemikian rupa sehingga mampu mengembangkan aspek-aspek life skills peserta didik. RPP mencakup pendekatan atau metode pembelajaran dan langkah-langkah pembelajaran yang akan diterapkan hal ini berpengaruh dalam pengembangan aspek life skills siswa baik kecakapan personal maupun kecakapan sosial. Tentunya dalam hal ini SD Muhammadiyah 9 Malang telah menyusun RPP yang di dalamnya dengan jelas dipaparkan kegiatan pembelajaran mana yang termasuk 4C (Communication, Collaborative, Critical Thinking dan Creativity) serta PPK (Penguatan Pendidikan Karakter) di dalamnya. Contoh PPK yang tertera dalam RPP yaitu religius, cinta tanah air (nasionalis), gotong royong, percaya diri, mandiri, integritas, keberanian, dan toleransi. Sehingga aspek kecakapan yang ingin dikembangkan pada peserta didik sudah terencana dan kegiatan pembelajaran dilaksanakan sesuai dengan rancangan pembelajaran yang sudah dibuat.

Selain kegiatan intrakurikuler, kegiatan ekstrakurikuler juga berpengaruh dalam kegiatan pengembangan life skills peserta didik. Peserta didik dengan mengikuti kegiatan ekstrakurikuler mampu mengetahui apa yang menjadi minat untuk selanjutnya dapat digunakan sebagai wadah untuk aktualisasi diri. Selain kegiatan intrakurikuler dan ekstrakurikuler, kokurikuler juga berpengaruh dalam pengembangan life skills peserta didik yaitu melalui program penguatan pendidikan karakter. Kegiatan ko-kurikuler secara tidak langsung mampu membentuk karakter peserta didik yang dibutuhkan juga dalam aspek kecakapan sosial maupun kecakapan personal. Kegiatan ko-kurikuler dapat dibentuk melalui program penguatan pendidikan karakter

Penguatan Pendidikan Karakter di SD Muhammadiyah 9 Malang antara lain upacara bendera, mengaji, tahfidz quran dan doa-doa harian, sholat dhuhur dan ashar berjamaah, sholat dhuha, kultum, kegiatan keputraan (sholat jum'at) dan keputrian (materi agama islam), pengumpulan infaq peserta didik, kunjungan ke panti asuhan malang raya, pembiasaan: kultum, adzan, dan iqomah, menyanyikan lagu nasional, pembelajaran keluar, senam ceria, kerjabakti kelas dan lingkungan sekitar, literasi, makan siang bersama, pembiasaan adab makan dan minum, menyambut kedatangan peserta didik pagi hari salam, salim, berdoa, dan password bahasa arab, pembiasaan cuci tangan dan gosok gigi, pemberian sertifikat bagi tahfidz al quran dan lulus tilawati, pembentukan tim karakter

\section{Sumber-Sumber Belajar yang Digunakan untuk Optimalisasi Pembelajaran dengan Muatan Life skills}

Sumber-sumber belajar turut membantu optimalisasi pembelajaran di kelas. Sumber belajar merupakan semua yang dapat digunakan dalam proses pembelajaran agar peserta didik dapat memperoleh informasi terkait suatu topik pembelajaran. Sumber-sumber belajar dapat berupa benda, manusia maupun lingkungan. Semua menjadi sumber belajar perlu direncanakan sedemikian rupa agar sesuai dengan topik pembelajaran. Hal ini, dapat dituangkan dalam Rancangan Pelaksanaan Pembelajaran (RPP) oleh guru untuk memudahkan pada saat proses pembelajaran.

Guru adalah salah satu komponen sumber belajar berupa manusia. Komponen tersebut merupakan sumber belajar utama dalam suatu pembelajaran karena semua komponen sumber belajar dapat terlaksana dengan optimal dengan diimbangi sumber belajar berupa manusia. Manusia tidak hanya sebagai sumber informasi tetapi juga dapat menjadi pengarah peserta didik dalam memperoleh informasi dari sumber belajar lain seperti buku, media elektronik, dan lain sebagainya.

\section{PEMBAHASAN}

\section{Struktur kurikulum 2013 yang diterapkan di SD Muhammadiyah 9}

Struktur kurikulum berdasarkan Kemendikbud (2013) terdiri atas kompetensi inti, kompetensi dasar, mata pelajaran dan beban belajar. Komponen mata pelajaran tersebut sesuai ketentuan yang ada di peraturan menteri pendidikan dan kebudayaan nomor 67 tahun 2013 tentang kerangka dasar dan struktur kurikulum sekolah dasar/madrasah ibtidaiyah berisikan muatan pendidikan agama dan budi 
pekerti, pendidikan pancasila dan kewarganegaraan, bahasa Indonesia, matematika, ilmu pengetahuan alam, ilmu pengetahuan sosial, seni budaya dan keterampilan, pendidikan jasmani dan olahraga.

Dari segi beban belajar seperti yang dijelaskan pada permendikbud nomor 67 tahun 2013 bahwa untuk kelas I beban belajar selama 30 jam dalam satu minggu. Kelas II beban belajar selama 32 jam dalam satu minggu. Kelas III beban belajar selama 34 jam dalam satu minggu. Kelas IV, V, dan VI memiliki beban belajar yang sama yaitu 36 jam dalam satu minggu. Kompetensi Inti sebagaimana tercantum pada permendikbud nomor 67 tahun 2013 Kompetensi inti mencakup 4 kompetensi: (1) Kompetensi Inti-1 (KI-1) untuk kompetensi inti sikap spiritual (2) Kompetensi Inti-2 (KI-2) untuk kompetensi inti sikap sosial (3) Kompetensi Inti-3 (KI-3) untuk kompetensi inti pengetahuan (4) Kompetensi Inti-4 (KI-4) untuk kompetensi inti keterampilan

\section{Jenis-Jenis Life skills yang Termuat dalam Kurikulum 2013 di SD Muhammadiyah 9 Malang}

Life skills atau kecakapan hidup menurut Depdiknas (2007) dibagi menjadi dua jenis yaitu: kecakapan hidup generik (general life skills/GLS) dan kecakapan hidup spesifik (specific life skills/ SLS). Pada jenjang pendidikan dasar lebih ditekankan pada general life skills. General life skills mencakup kecakapan personal dan kecakapan sosial. General Life Skills berisi tentang kecakapan personal dan kecakapan sosial. Kecakapan personal mencakup kecakapan dalam memahami diri sendiri (self awareness skill) dan kecakapan berpikir (thinking skill). Sedangkan kecakapan sosial terdiri atas kecakapan berkomunikasi (communication skill) dan kecakapan bekerja sama (collaboration skill). Bila dilihat dari aspek general life skills sendiri diterapkan melalui kegiatan pembelajaran di kelas maupun pada kegiatan ekstrakurikuler.

Kecakapan personal mencakup kecakapan dalam memahami diri sendiri (self awareness skill) dan kecakapan berpikir (thinking skill). Sedangkan kecakapan sosial terdiri atas kecakapan berkomunikasi (communication skill) dan kecakapan bekerja sama (collaboration skill). Bila dilihat dari aspek general life skills sendiri diterapkan melalui kegiatan pembelajaran di kelas maupun pada kegiatan ekstrakurikuler.

Kecakapan memahami diri sendiri dapat diperoleh melalui kegiatan intrakurikuler, kegiatan ekstrakurikuler maupun kegiatan kokurikuler. Kecakapan memahami diri sendiri pada kegiatan intrakurikuler dapat dilihat dari minat peserta didik dalam mengikuti pembelajaran dikelas. Pada kegiatan ekstrakurikuler dapat dilihat dari minat peserta didik dalam memilih dan mengikuti apa yang diminati. Pada kegiatan kokurikuler dapat diperoleh melalui program penguatan pendidikan karakter yang dapat membentuk kepribadian peserta didik.

Kecakapan berpikir dapat diperoleh dengan peserta didik secara aktif mengikuti pembelajaran di sekolah, mampu mengerjakan tugas atau soal yang diberikan oleh guru, mampu mengambil keputusan dengan cerdas. Kecakapan berkomunikasi dapat diperoleh dengan interaksi sosial peserta didik di sekolah baik dengan peserta didik lain, guru, maupun di lingkungan sekitar. Kecakapan bekerjasama dapat diperoleh melalui kegiatan pengerjaan tugas secara berkelompok dalam kegiatan pembelajaran.

\section{Penerapan Macam-Macam Life Skills dalam Kegiatan Pembelajaran}

Life Skills dapat diperoleh melalui kegiatan intrakurikuler, ekstrakurikuler, maupun, ko-kurikuler. Kegiatan intrakurikuler, kokurikuler, dan ekstrakurikuler pada Permendikbud Nomor 23 Tahun 2017 tentang Hari Sekolah disebutkan bahwa: Kegiatan intrakurikuler adalah suatu kegiatan yang dilaksanakan untuk pemenuhan kurikulum sesuai dengan peraturan perundang-undangan. Kegiatan kokurikuler adalah kegiatan yang untuk penguatan kompetensi dasar pada mata pelajaran sesuai dengan kurikulum. Sedangkan kegiatan ekstrakurikuler adalah kegiatan yang bertujuan untuk mengembangkan potensi, bakat minat, kepribadian, kerjasama, kemandirian peserta didik.

Penerapan aspek life skills tersebut terintegrasi dengan mata pelajaran. Seperti yang diungkap pada penelitian yang diungkap oleh Nizhomi (2014) bahwa "pada mata pelajaran Pendidikan Kewarganegaraan 
bahwa hampir semua guru mengintegrasikan kecakapan hidup dengan mata pelajaran yang diajarkan". Guru mengintegrasikan aspek general life skills dalam silabus dan RPP pada kegiatan pembelajaran.

Pada RPP terdapat pendekatan dan metode pembelajaran yang akan digunakan sehingga memudahkan guru untuk menentukan langkah-langkah pada kegiatan pembelajaran. Langkah-langkah pada kegiatan pembelajaran juga dijabarkan pada bagian mana aspek kecakapan yang akan diajarkan, seperti aspek komunikasi, berpikir kritis, kolaborasi, percaya diri.

\section{Sumber-Sumber Belajar yang Digunakan untuk Optimalisasi Pembelajaran dengan Muatan Life Skills}

Sumber belajar menurut berbagai pandangan para ahli dikategorikan menjadi beberapa jenis. Seperti yang diungkapkan Majid (2013) bahwa sumber belajar diklasifikasikan menjadi empat kategori yaitu, tempat atau lingkungan alam sekitar, benda, orang dan buku. Bila diklasifikasikan menurut pendapat di atas sumber belajar di SD Muhammadiyah 9 Malang yang termasuk tempat dan lingkungan alam sekitar adalah lingkungan sekolah dan lingkungan luar sekolah. Sumber belajar berupa benda antara lain lembar kerja peserta didik, televisi, komputer, proyektor, sound, maket dan alat peraga.

Sementara menurut AECT (Associaton for Education Corporation and Technology) sumber belajar dikategorikan menjadi 6 yaitu pesan, manusia, bahan atau perangkat lunak, peralatan atau perangkat keras, teknik atau metode, dan lingkungan. Pengklasifikasian sumber belajar berdasarkan AECT lebih kompleks dan rinci. sumber belajar berupa pesan dapat berupa buku tematik, teks bacaan, literature, dan lembar kerja peserta didik. Sumber belajar berupa manusia dapat berupa guru, narasumber, dan teman sejawat. Sumber belajar berupa bahan dapat berupa film, video, slide ppt, gambar. Sumber berupa teknik yaitu dapat berupa diskusi, kerja kelompok, tanya jawab, belajar mandiri, brainstorming, silent reading (membaca dalam hati), pengamatan dan penugasan. Serta sumber belajar berupa lingkungan berupa lingkungan sekolah dan lingkungan luar sekolah.

Sumber-sumber belajar tersebut disesuaikan dengan materi pembelajaran. Sumber-sumber belajar tersebut dapat direncanakan dan dituangkan dalam RPP dan silabus untuk memudahkan guru dalam memulai proses pembelajaran yang akan dilakukan di kelas. RPP dibuat sebelum proses pembelajaran dilakukan di kelas. RPP disusun secara sistematis dengan berisikan data kompetensi inti, kompetensi dasar dan indikator, tujuan pembelajaran, pendekatan dan metode pembelajaran, sumber-sumber belajar, langkah-langkah pembelajaran, dan penilaian hasil belajar. Sumber-sumber belajar tersebut disesuaikan dengan tema pembelajaran yang akan diajarkan kepada peserta didik. Hal ini bertujuan agar peserta didik dapat memahami materi yang diajarkan dengan lebih optimal sekaligus juga dapat digunakan oleh guru untuk melakukan kegiatan variasi pembelajaran dikelas agar pembelajaran tidak membosankan.

\section{SIMPULAN DAN SARAN}

\section{Simpulan}

SD Muhammadiyah 9 Malang menerapkan kurikulum 2013 sebagai pedoman dalam pelaksanaan kurikulum di sekolah sesuai ketentuan dari dinas pendidikan. Akan tetapi selain acuan dari dinas pendidikan SD Muhammadiyah 9 dari segi pembelajaran keislamannya menggunakan "Ismuba" yaitu singkatan dari keislaman, kemuhammadiyah dan bahasa arab. Struktur kurikulum di SD Muhammadiyah 9 Malang yang terdiri atas terdiri atas kompetensi inti, kompetensi dasar, mata pelajaran dan beban belajar.

Jenis-jenis life skill berdasarkan general life skills terdiri atas kecakapan personal dan kecakapan sosial. Berdasarkan hasil penelitian di SD Muhammadiyah 9 Malang jenis kecakapan antara lain, kecakapan memahami sendiri, kecakapan berpikir, kecakapan berkomunikasi, dan kecakapan bekerjasama. Berdasarkan hasil penelitian kecakapan memahami diri sendiri dapat diperoleh melaui kegiatan intrakurikuler, ekstrakurikuler dan kokurikuler untuk membentuk kepribadian peserta didik maupun menemukan kegemaran. Kecakapan berpikir dapat diperoleh melalui kegiatan intrakurikuler 
yaitu melalui kegiatan pembelajaran yang diperlukan kemampuan peserta didik secara aktif berpikir kritis. Kecakapan berkomunikasi dapat diperoleh melalui interaksi sosial dengan peserta didik lain, guru, maupun di lingkungan sekitar. Kecakapan bekerjasama dapat diperoleh dengan kegiatan pengerjaan tugas secara berkelompok di sekolah.

Life Skills dapat diperoleh melalui kegiatan intrakurikuler, ekstrakurikuler, maupun, ko-kurikuler. Penerapan aspek life skills tersebut terintegrasi dengan mata pelajaran. RPP yang disusun mencakup pendekatan atau metode pembelajaran dan langkah-langkah pembelajaran yang akan diterapkan hal ini berpengaruh dalam pengembangan aspek life skills siswa baik kecakapan personal maupun kecakapan sosial. Tentunya dalam hal ini SD Muhammadiyah 9 Malang telah menyusun RPP yang di dalamnya dengan jelas dipaparkan kegiatan pembelajaran mana yang termasuk 4C (Communication, Collaborative, Critical Thinking dan Creativity) serta PPK (Penguatan Pendidikan Karakter) di dalamnya. PPK yang tertera dalam RPP yaitu religius, cinta tanah air (nasionalis), gotong royong, percaya diri, mandiri, integritas, keberanian, dan toleransi. Sehingga aspek kecakapan yang ingin dikembangkan pada peserta didik sudah terencana dan kegiatan pembelajaran dilaksanakan sesuai dengan rancangan pembelajaran yang sudah dibuat.

Sumber-sumber berdasarkan hasil penelitian yang termasuk dalam pesan antara lain buku tematik, teks bacaan, literature, lembar kerja peserta didik. Sumber belajar berupa manusia yaitu ustad dan ustadzah, narasumber, dan teman sejawat. Sumber belajar berupa bahan yaitu film, video, slide ppt, gambar. Sumber belajar berupa alat yaitu televisi, komputer, proyektor, sound, maket, alat peraga. Sumber belajar berupa teknik yaitu diskusi, kerja kelompok, tanya jawab, belajar mandiri, brainstorming, silent reading (membaca dalam hati), pengamatan, penugasan. Sumber belajar berupa lingkungan yaitu lingkungan sekolah dan lingkungan luar sekolah. Sumber belajar tersebut merupakan komponen penudukung dalam optimalisasi penerapan pembelajaran di sekolah.

\section{Saran}

Peneliti lain dengan penelitian sejenis dapat menjadikan skripsi ini sebagai referensi serta dapatmelanjutkan penelitian tentang life skill

\section{DAFTAR RUJUKAN}

Depdiknas. (2007). Konsep Pengembangan Model Integrasi Kurikulum Pendidikan Kecakapan Hidup (Pendidikan Menengah). Jakarta: Badan Penelitian dan Pengembangan Pusat Kurikulum.

Kementerian Pendidikan dan Kebudayaan. (2013). Kerangka Dasar dan Struktur Kurikulum 2013. Jakarta: Kemendikbud.

Majid, A. (2013). Strategi Pembelajaran. Bandung: Remaja Rosdakarya.

Nizhomi, B. (2014). Integrasi General Life Skill dalam Pembelajaran Pendidikan Kewarganegaraan Kelas V di MIN Jejeran Bantul Yogyakarta, (Online) (digilib.uin-suka.ac.id/id/file/120140), diakses 15 Februari 2018.

Peraturan Menteri Pendidikan dan Kebudayaan Nomor 67 Tahun 2013 Tentang Kerangka Dasar dan Struktur Kurikulum Sekolah Dasar/Madrasah Ibtidaiyah, (Online), (http://simpuh.kemenag.go.id/regulasi/ permendikbud_67_13_lampiran.pdf), diakses 7 Maret 2019.

Permendikbud Nomor 23 Tahun 2017 Tentang Hari Sekolah, (Online), (https://sahabatkeluarga.kemdikbud.go.id/ kecil/wp-content/uploads/2018/12/Permendikbud-No-23-Tahun-2017-tentang-Hari-Sekolah.pdf), diakses 21 Juli 2019.

Undang-Undang RI Nomor 20 Tahun 2003 Tentang Sistem Pendidikan Nasional. Bandung: Citra Umbara.

Wahab, R. (2012). Reformulasi Inovasi Kurikulum: Kajian Life Skill Untuk Mengantarkan Peserta Didik Menjadi Warga Negara Yang Sukses, (Online), (http://jurnal.radenfatah.ac.id/index.php/tadib/article/download/33/28), diakses 15 Februari 2018.

Yuliwulanda, N. (2017). Pengembangan Muatan Kecakapan Hidup (Life Skill) Pada Pembelajaran Di Sekolah, (Online), (http://download.portalgaruda.org/article.php), diakses 15 Februari 2018. 